\title{
Sylwia Urbańska
}

Wydział Socjologii

Uniwersytet Warszawski

urbanskas@is.uw.edu.pl

\section{(NIE)MOBILNOŚĆ, ZAMIESZKIWANIE ORAZ PLEĆ W PRAKTYKACH I DYSKURSACH ROZWODU W WIEJSKIEJ SPOLECZNOŚCI ROLNICZEJ GMINY WSCHODNIEGO MAZOWSZA}

\section{(Im)mobility, residence and gender in divorce practices and discourses in the rural farming community of East Mazovia}

Streszczenie. W artykule analizuję relacje między upłciowionymi praktykami i dyskursami rozwodu w wiejskiej społeczności a ścieżkami (nie)mobilności mieszkanek wsi. Pokazuję, że „pionierki rozwodu”, czyli kobiety z rolniczych, konserwatywnych społeczności, które w lokalnym świecie społecznym jako pierwsze przeprowadziły rozwód, wypracowały alternatywne strategie pozostawania na wsi. Nie chciały uciekać, wyjeżdżać, emigrować na stałe do miasta lub za granicę, czyli korzystać z typowej ścieżki stawania się ex-żoną. Opisuję, jakie wzorce radzenia wypracowywały po 1989 roku, aby nadal móc we wsi mieszkać. Wyjaśniam subwersje stosunku do własności i dziedziczenia, ich związki z tradycyjnymi wzorcami kobiecości i męskości. Skupiam się na upłciowionych wzorcach (nie)mobilności w tym przypadku będących strategiami wyboru wsi jako miejsca do życia. Wnioski prezentuję w ramach studium przypadku Mirki, wielodzietnej matki, która po rozwodzie traci swój dom, co sprawia, że musi rozwinąc sprawcze wzorce radzenia sobie. Praktyki Mirki pokazuję na tle innych wariantów działania i dyskursów moralnych wokół rozwodu w badanej przeze mnie od 2017 roku gminie wschodniego Mazowsza. 
(Nie)mobilność, zamieszkiwanie oraz płeć w praktykach i dyskursach rozwodu

Kluczowe słowa: rozwód, wieś, dyskursy moralne, mobilność, zamieszkiwanie, mieszkanki wsi

\begin{abstract}
In this article, I analyze the relationship between the gendered practices and discourses of divorce in rural communities and the (im)mobility paths of rural women. I show that the "pioneers of divorce", that is, women from the agricultural, conservative communities who were the first to divorce in the local social world, developed alternative strategies for staying in the countryside. They did not want to run away, leave, or emigrate permanently to the city or abroad, that is, use the typical path of becoming an ex-wife. I describe the coping patterns they developed after 1989 in order to still be able to live in the village. I explain the subversions of ownership and inheritance, their relationship to traditional patterns of femininity and masculinity. I focus on the gendered patterns of (im)mobility in this case as strategies for choosing the countryside as a place to live. I present my conclusions in the case study of Mirka, a mother with many children, who loses her home after divorce, which means that she must develop coping patterns. I show Mirka's practices against the background of other variants of practices and moral discourses around divorce in the commune of eastern Mazovia, which I have studied since 2017.
\end{abstract}

Key words: divorce, village, moral discourses, mobility, housing, village inhabitants

Cofnijmy się na chwilę do roku 1932, do wiejskiego dworku średnio zamożnego ziemiaństwa z dzisiejszego wschodniego Mazowsza ${ }^{1}$. Jego mieszkanka, być może pani domu, choć bardziej prawdopodobne, że guwernantka, kucharka, czyta ,Wiadomości Kobiece”. To tygodnik

1 Źródło finansowania: grant Narodowego Centrum Nauki „Sonata” pod tytułem „(Nie)tradycyjni tradycyjni? Przemiany rodzin wiejskich z perspektywy kobiet w latach 1989-2019", numer 2016/23/D/HS6/00705, kierowniczka projektu - dr Sylwia Urbańska, Wydział Socjologii, Uniwersytet Warszawski. Za uwagi do tekstu dziękuję anonimowym recenzentom, za korektę językową ostatniej wersji dziękuję Marcie Abramowicz. 
o treściach emancypacyjnych, skierowany do kobiet z prowincji, które ,gazet dotychczas nie czytywali”. Według redakcji pierwszy demokratyczny, bo kilkunastokrotnie tańszy niż gazeta codzienna, co więcej „przystosowany do dalekich, zapylonych dróg i docierający tam, gdzie się karetą nie dojedzie, gdzie się gładkim wytartym słowem serc nie zdobędzie" (Zdanowicz 2017: 48). To właśnie numer tego pisma z 1932 roku znajduję w trakcie badań terenowych. Jest wyłożony w gablocie przekształconego na muzeum ziemiańskiego dworku. Na mocno pożółkłej już okładce widnieje tytuł: „Nowa ustawa małżeńska w Belgii”, a tekst informuje ówczesne czytelniczki o nowym, belgijskim prawie rozwodowym. Dowiadujemy się o porażce sufrażystek, którym, podobnie jak działaczkom w Polsce, nie udało się jeszcze wywalczyć podstawowych praw rozwodzących się kobiet - prawa do podziału majątku, zabezpieczenia mieszkania czy prawa matki do zachowania opieki nad dzieckiem²

Dzisiaj już wiadomo, że praktycznie żadna z ówczesnych czytelniczek tygodnika nie mogła się rozwieść. Ani mieszkanka dworku, gdzie teraz znajduje się muzeum, ani żadna $\mathrm{z}$ dobrze urodzonych kobiet w sąsiednich majątkach, ani nawet mieszkanka pałacu. Jak pokazuje historyczka Barbara Klich-Kluczewska, wywalczenie przez Polki prawa do głosowania w 1918 roku nie równało się wprowadzeniu równości małżeńskiej w prawie cywilnym. W całym dwudziestoleciu międzywojennym rozwód był praktycznie nieznany. Rozwodziły się głównie osoby innych niż katolickie wyznań lub ze związków mieszanych religijnie. Byli to mieszkańcy miast, specyficzne grupy jak np. artyści i wojskowi (Klich-Kluczewska 2015). Natomiast dla chłopek rozwód był niemożliwy do przeprowadzenia. $Z$ innych prowadzonych przeze mnie badań wiem, że jako grupa były one mimo wszystko w lepszej sytuacji niż kobiety z wyższych warstw. Te które migrowały za granicę, mogły skorzystać z relatywnie bardziej demokratycznego prawa rozwodowego i wsparcia towarzystw dobroczynnych. Pod warunkiem, że udało im się dopłynąć za ocean (Urbańska 2018).

2 Tekst redakcyjny, bez autora/autorki. Wiadomości Kobiece, Rok II, 42(58), 16.10.1932, s. 1. 
(Nie)mobilność, zamieszkiwanie oraz płeć w praktykach i dyskursach rozwodu

Wróćmy teraz do współczesności, pozostając jednak w tej samej lokalizacji, badanej przeze mnie wiejskiej gminie wschodniego Mazowsza, potocznie nazywanego ,polskim pasem biblijnym” ze względu na wysokie wskaźniki religijności. Prawie sto lat później sytuacja z rozwodem nie ulega tutaj większym zmianom. Z prowadzonych przeze mnie od 2017 roku badań praktyk rodzinnych wiem, że w najstarszym pokoleniu rozwodów praktycznie nie było. O rozwód pytam starsze kobiety, przeszukuję archiwa. Córki i wnuczki wypytuję o herstoryczne przekazy międzygeneracyjne. Interesuje mnie życie ich babek, matek, ciotek. W lokalnej pamięci rozwód najstarszego pokolenia praktycznie nie istnieje, mimo że demokratyczne prawo do rozwodu tuż po II wojnie światowej wprowadzono wraz z ustrojem socjalistycznym (Klich-Kluczewska 2015). Moi rozmówcy, zarówno kobiety, jak i mężczyźni, potrafią za to wskazać, która z kobiet jako pierwsza rozwiodła się we wsi. Doskonale orientują się, która po rozwodzie wyemigrowała, a która przeprowadziła się do wynajętego lub zakupionego przez siebie starego domu w sąsiedztwie lub kilka miejscowości dalej. Wskazywaną przez wiele osób w jednej z badanych wsi ,pionierką" (tak będę nazywać kobiety z tej grupy) okazuje się prawie pięćdziesięciolatka, która rozwiodła się po 2000 roku. Jest jedną z nielicznych, rozwiedzionych kobiet stanowiących 2\% spośród 2500 mieszkańców gminy. To o wiele mniej niż średnia dla Polski, która dla rozwiedzionych i w separacji wynosi 6\% (GUS 2018).

Demokratyzacja prawa rozwodowego nie otworzyła do niego równego dostępu. Część ekonomicznych, społecznych i mentalnych barier jest nadal silna w badanych przeze mnie wsiach. Co tak naprawdę wiemy o tym, jak przebiegał i przebiega rozwód, zwłaszcza gdy pytamy o doświadczenia mieszkanki rolniczych, katolickich wsi? A więc takich, które są najbliższe modelowi tradycyjnej wsi w Polsce ze względu na wciąż obecne i silne wzorce patriarchalne w rodzinie i lokalnej sferze publicznej. Odpowiedź na to pytanie interesuje mnie szczególnie w kontekście relacji między rozwodem a praktykami (nie)mobilności. Skupię się zatem na analizie możliwości i barier zamieszkiwania kobiet na wsi w sytuacji reorganizacji życia po rozpadzie związku. Moim wkładem do aktualnego stanu badań jest pokazanie alternatywnych wzorców praktyk podejmowanych 
w celu pozostania na wsi po rozwodzie. Do tej pory historycznie ugruntowanymi strategiami radzenia sobie z nienormatywnymi scenariuszami biograficznymi na wsi były przede wszystkim wyjazdy, emigracja, wychodźstwo. Dzisiaj, mimo rozlicznych przeciwności, mieszkanki terenów wiejskich próbują sprawczo radzić sobie z wielokrotnymi wykluczeniami, których doświadczają po rozpadzie małżeństwa.

Interesujące mnie zagadnienia analizuję za pośrednictwem studium przypadku Mirki, wielodzietnej matki, która po rozwodzie wpada w typową trajektorię utraty domu i miejsca zamieszkania. Sprawstwo Mirki pokazuję na tle innych wariantów praktyk i dyskursów moralnych wokół rozwodu w badanej od 2017 roku rolniczej gminie wschodniego Mazowsza.

\section{Płeć i wiejski rozwód wobec mobilności i zamieszkania}

Jak zatem można w świetle zastanej literatury wytłumaczyć problemy z dostępnością rozwodu dla mieszkanek wsi? Czy nadal jest on utożsamiany w lokalnych dyskursach z koniecznością wyjazdu, emigracji, wychodźstwa ze wsi? Dlaczego warto badać relacje między wiejskim rozwodem i płcią a mobilnością oraz zamieszkiwaniem? W jakich perspektywach analizować te związki?

Kiedy przeanalizowałam aktualny stan badań nad zjawiskiem rozwodu w Polsce, odniosłam wrażenie, że jest on powszechnie dostępną i znormalizowaną formą zakończenia nieudanego małżeństwa. Analiza aktualnego stanu badań nad zjawiskiem rozwodu w Polsce pokazuje, że fenomen wydaje się jednak interesować głównie demografów. Badań jakościowych obejmujących ostatnie 30 lat jest niewiele w porównaniu do ogromnego zainteresowania problematyką rozwodu w okresie PRL ${ }^{3}$. Statystyki z ostatnich dwóch dekad pokazują idące ostro w górę krzywe

${ }^{3} \mathrm{O}$ ile rozwód sam w sobie w wymiarze złożoności jego doświadczenia nie zwrócił po 1989 roku większej uwagi socjologów jakościowych i antropologów, sporo wiedzy na temat kontekstów wiejskiego rozwodu wnoszą coraz liczniejsze w ostatnim czasie analizy feministycznie zorientowanych historyczek i osób badających migracje. Analizy te oczywiście korzystają z bogatej literatury badań nad rozwodem z okresu PRL. 
(Nie)mobilność, zamieszkiwanie oraz płeć w praktykach i dyskursach rozwodu

rozwodzących się małżeństw. Rozpada się jedna trzecia z nich - ok. 40\% w mieście, a $20 \%$ na wsi (Szukalski 2019). W przestrzeni publicznej obecne są postulaty środowisk religijno-konserwatywnych kładące nacisk na nierozerwalność małżeństwa, nie ma natomiast przeciwwagi w postaci postulatów ze strony ruchów lewicowo-progresywnych, które domagałyby się lepszej dostępności rozwodów. Liczne kampanie antyrozwodowe mogą wywoływać poczucie jego masowości, a więc i powszechnej dostępności (Urbańska 2011). W efekcie rozwód może uchodzić za dawno już zdobyty przyczółek na polskiej ścieżce emancypacji, nie warty innej niż statystyczna uwagi. Nic bardziej mylnego, czego przykładem jest zarysowana na wstępie historia nieobecności wiejskiego rozwodu w badanej przeze mnie rolniczej gminie. Pojawia się on w doświadczeniu mieszkanek wsi oraz w świadomości mieszkańców dopiero od niedawna.

\section{Wieś, płeć i rozwód}

Jeśli spojrzymy na ogólnopolskie dane statystyczne, zauważymy, że rozwód w społeczności wiejskiej to fenomen obecny na szerszą skalę zaledwie od dwóch dekad. Jeszcze w latach 70 . XX wieku na 1000 rozwodów w Polsce zaledwie 3,5 notuje się na wsi (Klich-Kluczewska 2015: 144-145). Można powiedzieć, że dopiero dekadę po transformacji ustrojowej w 1989 roku, zjawisko to zaczęło być widoczne i z roku na rok nabierało rozpędu. Na początku lat dwutysięcznych statystycznie jeden z ośmiu rozwodów w Polsce przebiegał na wsi, a w 2018 roku był to nawet co czwarty rozwód (GUS 2019). Mowa tu jednak o historycznie bardziej liberalnych obyczajowo zachodnich regionach kraju (Szukalski 2019). Widzimy zatem, że wieś dopiero dekadę po 1989 roku musiała w bardzo szybkim tempie skonfrontować się nie tylko z tym indywidualnym, ale i zbiorowym fenomenem. Praktyki wywodzących się ze średniego pokolenia ,pionierek” rozwodu z badanych przeze mnie wsi zderzyły się z transmitowaną międzygeneracyjnie, obecną w lokalnych dyskursach, kulturą wstydu, wykluczenia i stygmatyzacji. Kulturą mocno naznaczoną nierównościami genderowymi. 
Rozwód na wsiach w PRL był rzeczą wyjątkowo rzadką i bardzo wstydliwą (Tryfan, Grabowicz 1962; Szpakowska 2013: 180). Feministycznie zorientowane historyczki i badaczki wsi zwracały uwagę, że ogromną rolę $\mathrm{w}$ patologizacji rozstania - od czasu sekularyzacji prawa rozwodowego - odegrał o wiele bardziej znaczący na wsi niż w mieście Kościół katolicki. W odczytywanych w czasie kazań listach pasterskich Kościół o rzekomą „epidemię” rozwodów oskarżał kobiety, obwiniał je o niemoralność i odrzucenie ideału poświęcającej się, heroicznej żony. Źródło zła lokował wprost w promowanej w socjalizmie pracy kobiet poza domem (Klich-Kluczewska 2015: 153; zob. Bernini 2020). Poza tym w całej Polsce rozwód jako moralne tabu był napiętnowany. Kobiety, które zdecydowały się na rozwód, były odrzucane i postrzegane jako zdemoralizowane znacznie bardziej niż mężczyźni (Klich-Kluczewska 2015: 151-156). Pewnym wyjątkiem od tej reguły były PGR-y, gdzie sankcje społeczne wobec praktyk rodzinnych kobiet (rozwód, samotne macierzyństwo) były relatywnie mniejsze (Michalska 2019).

Wieś stanowiła zresztą szczególną przestrzeń społeczno-kulturową i ekonomiczną dla reprodukcji tego podwójnego standardu i związanego z nim wstydu, obcości, czy stygmatyzacji wynikających z naruszenia moralnych reguł wspólnoty. Podstawą tego rodzaju presji i kontroli było przekonanie o właściwym i naturalnym porządku moralnym, wyznaczającym miejsca kobiet i mężczyzn w przestrzeni społecznej wsi. Dla kobiet tym miejscem był dom wraz z gospodarstwem, stąd role im przypisywane były ściśle związane z „kulturą udomowienia” i obejmowały pracę opiekuńczą na rzecz rodziny, gospodarstwa rolnego i dobra wiejskiej wspólnoty (Hughes 1997; Little 2007; Michalska 2015). Nawet jeśli aprobowano pracę poza gospodarstwem i rodziną, jak miało to miejsce w krajach socjalistycznych, wartość pracy kobiet miała wobec nich funkcjonalne, służebne znaczenie. Była uzasadniana, o ile wynikała z niezbywalnych potrzeb gospodarstwa i rodziny (Pine 2007; Dunn 2007). Uzasadniano ją też w przypadku, gdy wiązała się z zastąpieniem nieobecnego mężczyzny (Michalska 2019).

Oczekiwania zbudowane na tak rozumianych obowiązkach stwarzały presję na poświęcenie swoich indywidualnych potrzeb i interesów na 
(Nie)mobilność, zamieszkiwanie oraz płeć w praktykach i dyskursach rozwodu

rzecz szeroko rozumianego dobra rodziny. To rodzina jako całość, a nie jednostka, była podstawową komórką wiejskiej wspólnoty (BukrabaRylska 2008). Oczekiwania obejmowały też dbanie przez kobietę o pozycję i prestiż rodziny w wiejskiej wspólnocie oraz parafii (Hughes 1997). Obligowały ją do heroizmu i poświęcenia na rzecz utrzymania ciągłości i przetrwania gospodarstwa rolnego (Shortall 2017; Brandth 2015; Haughen, Brandth, Follo 2015; w Polsce: Tryfan 1987; Knapik 2008; Krzyworzeka 2014; Michalska 2019). Wywierana na kobietach presja skłaniała je również do utrzymywania pożądanego wizerunku publicznego i statusu męskich członków rodziny - męża, ojca i teścia (Stanisz 2013; Urbańska 2015). W wymiarze praktycznym przekładało się to na większą władzę mężczyzn w obszarze dziedziczenia i własności gospodarstw rolnych i oczekiwaniu zadeklarowania męża jako głównej osoby prowadzącej gospodarstwo (Gorlach, Drąg 2011). Bycie rolnikiem, posiadanie gospodarstwa, ujarzmianie maszyn oraz wytrzymałość fizyczna są do tej pory fundamentalnym składnikiem wiejskich, hegemonicznych męskości (Gospodarczyk 2019). Wszystkie te wzorce przekładały się też na nierówności genderowe w obszarze władzy, własności i prawa do dysponowania nadwyżkami finansowymi. Krzysztof Gorlach i Zbigniew Drąg (2011) zwracają uwagę, że we współczesnej Polsce tylko 30\% gospodarstw jest prowadzonych przez kobiety. Przejmują je dopiero w sytuacji konieczności. Przymus jest podyktowany najczęściej śmiercią lub chorobą mężczyzny, brakiem innych męskich krewnych zdolnych do dziedziczenia, a więc ryzykiem likwidacji gospodarstwa. Reprodukowane są zatem wzorce oczekiwań, zgodnie z którymi kobiety będą traktować swoje roszczenia majątkowe jako mniej ważne, drugorzędne wobec potrzeb bliskich im mężczyzn. W przypadku planów rozwodu będą poświęcały swoje prawa na rzecz dobrostanu wspólnoty i gospodarstwa, najlepiej zupełnie rezygnując z udziałów w tym ostatnim (Shortall 2017).

Taki układ relacji między płciami w porządkach moralnych wsi wykształcił silną kontrolę w społecznościach. Przetrwała ona do dzisiaj w zróżnicowanej formie i natężeniu, mimo intensywnej zmiany społecznej i różnicowania samych wsi. Jej siłę i skuteczność nazywa się w literaturze „wiejskim panoptykonem” (Philo, Parr, Burns 2017). Powstaje on 
w następujących warunkach: niewielki obszar zamieszkania, brak anonimowości, kontrola sąsiedzka, bliskie związki mieszkańców i ich znacznie większa homogeniczność kulturowo-religijna (Mohl 1997; Haugen, Villa 2006; Halamska 2011).

Drugą stroną kontroli tego opartego na nierównościach porządku płci jest kultura normalizacji i unieważnień różnego typu nadużyć, które mogłyby zagrozić ciągłości rodziny i gospodarstwa. Sztandarowym tego przykładem jest traktowanie przemocy domowej jako środka kontroli społecznej, jej niewidzialność czy umniejszanie znaczenia (Niczyporuk 2004; Urbańska 2015; Michalska 2016). Widać to doskonale, kiedy porównujemy statystyki deklarowanych przyczyn rozwodów w miastach i na wsiach. Przez długi czas, jeśli o rozwód wnioskowała mieszkanka wsi, działo się to dopiero z powodu doświadczania skrajnej przemocy. Tylko w takich sytuacjach część społeczności wiejskiej godziła się jakkolwiek legitymizować moralnie rozwód, choć równie silny pozostawał katolicki nacisk na nierozerwalność małżeństwa zmuszający żonę do heroicznego trwania u boku męża mimo trudności (Urbańska 2016).

\section{Wiejski rozwód a mobilność i pozostawanie na wsi}

Brak społeczno-kulturowej przestrzeni dla alternatywnych wobec konserwatywno-patriarchalnych wyborów życiowych powodował, że decyzje o rozwodzie zwykle były związane z koniecznością wyjazdu lub migracji ze wsi. W PRL trajektoria wiejskiego rozwodu, ale też innych przekroczeń genderowej normy, np. urodzenie dziecka przez kobietę niezamężną czy staropanieństwo, powiązane były nierzadko z wychodźstwem do miast (zob. Klich-Kluczewska 2015), choć było to zróżnicowane regionalnie (zob. Kowalska-Lewicka 1971). Natomiast już po 1989 roku, dzięki otwarciu granic, rozwód był realizowany w ramach wzorca migracji jako sposobu rozwiązywania ekonomiczno-rodzinnych problemów (Urbańska 2015). Nie wiemy jednak, jakie wzorce konstruowały ,pionierki”, które po rozpadzie małżeństwa zdecydowały się mieszkać na wsi. Potrzebujemy zatem nowej/ innej ramy teoretycznej i innej antropologiczno-socjologicznej opowieści. 
(Nie)mobilność, zamieszkiwanie oraz płeć w praktykach i dyskursach rozwodu

Szansę taką daje nam perspektywa (nie)mobilności (immobility perspective), rozwijana przez badaczy procesów pozostawania na wsi (Stockdale, Haartsen 2018). Proponuje ona krytyczne odchodzenie od dyskursu uznającego mobilność za uniwersalną, pożądaną dla rozwoju wartość. Dyskursu, który faktycznie zrównuje pozostawanie, np. wiejską (nie)mobilność, z „byciem nieudacznikiem” (Looker, Naylor, 2009), czy z „zacofaniem” (Ni Laoire 2001). Zauważa się, że paradygmat wartościujący mobilność jako praktykę pożądaną, w istocie ignoruje zarówno sprawczość osób, które chcą pozostawać, jak i skomplikowany charakter samej (nie)mobilności (Stockdale, Haartsen 2018: 2).

W zamian za to w perspektywie (nie)mobilności bada się pozostawanie jako proces dokonywania wyboru, który jest refleksyjny, celowy, aktywny, nigdy się nie kończy. Ludzie mogą chcieć pozostać, ale mogą nie być w stanie tego zrobić z powodu zróżnicowanych ograniczeń strukturalnych. Nie są w każdym razie biernymi obserwatorami własnego losu (Hjalm 2014: 579). Stąd w analizach procesów pozostawania uwzględnia się zarówno aspiracje, jak i możliwości zamieszkania w danym miejscu na różnych etapach życia, w tym różnorodne czynniki sprzyjające lub utrudniające. Do tych ostatnich zalicza się terytorialne i społeczne cechy poczucia przynależności, zakorzenienia i przywiązania do domu oraz miejscowości, między innymi rolę rodziny, przyjaciół i społeczności (Haukanes 2013).

Perspektywa (nie)mobilności odsłania ciekawe możliwości analiz sposobów wpisania wiejskiego rozwodu w kultury migrowania lub pozostawania (Nugin 2014). Tym bardziej, że rozwód będący specyficznym rytuałem przejścia wymusza konieczność renegocjacji wyboru miejsca zamieszkania (Clark 2013). Dlatego tak atrakcyjne wydaje się spojrzenie, jak rozwód wpisuje się w całościową ścieżkę zamieszkiwania (residential path) (Thomassen 2021) i w upłciowione rodzinne ścieżki mieszkaniowe (gendered family housing pathways) (Mostowska, Dębska 2020). Przebieg tych trajektorii, zwłaszcza w kontekście wiejskim, jest mocno wpisany w lokalną sferą publiczną z jej moralnymi dyskursami wokół rozwodu, mobilności i pozostawania. 


\section{Metodologia badań}

Analiza, którą tu rozwijam jest częścią większego badania „(Nie)tradycyjni tradycyjni? Przemiany rodzin wiejskich z perspektywy kobiet w latach 1989-2019" (NCN, 2016/23/D/HS6/00705). Celem projektu jest próba rozpoznania, czy i w jaki sposób zmieniają się modele relacji i role w wiejskich rodzinach w kontekście przemian wsi oraz szerszych przemian rodziny po 1989 roku w Polsce. Analiza związków między ścieżką rozwodu a praktykami (nie)mobilności mieszkanek wsi jest konsekwencją skupienia uwagi na relacjach w małżeństwach i związkach nieformalnych. Badam je w kontekście doświadczeń autobiograficznych kobiet, ale też w kontekście relacji tych doświadczeń do najbliższego otoczenia rodzinnego i społeczności wsi oraz ich porządków moralnych i instytucji.

Mówiąc o relacjach między ścieżką rozwodu a praktykami (nie)mobilności, skupiam się na rozpoznaniu nie tylko repertuarów możliwości, ale i barier pozostawania we wsi w relacji do społecznego procesu wychodzenia z małżeństwa, nazywanego przeze mnie procesem (od)stawania się żoną. Rozpoznaję i analizuję praktyki mobilności i decyzje mieszkaniowe kobiet oraz ich związek z lokalnymi oczekiwaniami, presjami, wzorcami moralnymi, które rozgrywane są w ramach wiejskich uwarunkowań strukturalnych.

Przedstawione tutaj wyniki są reprezentatywne jakościowo w dwóch wymiarach. Po pierwsze, wybrany obszar badań stwarza możliwość rozpoznania wzorców w typie wsi rolniczych, tradycyjnych. Jednocześnie są to wsie podlegające emancypacyjnej zmianie społecznej, w tym różnorodnym procesom dezagraryzacji (kurczenia się rolnictwa w strukturze wsi) i proletaryzacji. Wybór padł więc na gminę, w której kobiety muszą radzić sobie nie tylko z głęboko zakorzenionymi w historii konserwatywnymi oczekiwaniami, co do ich roli i statusu w rodzinie oraz sferze publicznej, ale także ze znaczącymi ograniczeniami strukturalnymi. Pod drugie, zebrane 30 narracji autobiograficznych pozwala z kolei na odtworzenie trajektorii doświadczeń i usytuowanie rozpoznanych wzorców w procesach długiego trwania. Natomiast wybór metody monograficznej opartej na długotrwałej obserwacji uczestniczącej i wywiadach umożliwia 
(Nie)mobilność, zamieszkiwanie oraz płeć w praktykach i dyskursach rozwodu

całościowe pokazanie zjawiska w kontekście jego związków z dynamicznie zmieniającym się światem społecznym wsi.

Kluczowe znaczenie dla zrozumienia specyfiki wyników ma celowy dobór rolniczej gminy wiejskiej o wysokich wskaźnikach tradycyjności, silnej obecności wzorców patriarchalnych, uwarunkowaniach strukturalnych wykluczających zwłaszcza kobiety (ale i mężczyzn). Do badań wybrałam gminę ulokowaną na terenie wschodniego Mazowsza, w której skład wchodzi 16 niewielkich wsi z aktualną liczbą 2500 mieszkańców. Gmina jest oddalona o kilkadziesiąt kilometrów od najbliższego dużego miasta. Liczne ograniczenia infrastrukturalne i ekonomiczne odbijają się w niskich dochodach mieszkańców i wysokim bezrobociu kobiet. Około 40\% z mieszkanek jest bezrobotnych lub pracuje dorywczo. Taka sytuacja ma związek z rolniczym charakterem gminy, gdzie ponad $60 \%$ osób deklaruję pracę w sektorze rolnym, w którym łatwiej o bezrobocie kobiet. Część z tych osób faktycznie podpada jednak pod kategorię ukrytego bezrobocia. Są to osoby, które nie mają więcej niż 2 hektary ziemi, więc nie mogą zarejestrować się jako bezrobotne, mimo że dochód z ewentualnych upraw nie zapewnia środków do przeżycia. Trudność ze znalezieniem pracy ma również związek z brakiem lokalnego przemysłu. Z względu na ekologiczne walory terenu, który stanowi część obszaru tzw. Podlasia Nadbużańskiego, objęto go programem Natura 2000. W konsekwencji nie ma więc możliwości budowania fabryk i dużych zakładów przemysłowych. Wiele osób utrzymuje się zatem z fizycznej i sezonowej pracy dorywczej w lokalnych sadach, pieczarkarniach, ubojniach, przedsiębiorstwach hodowli ryb. Część dorabia w dominujących tu gospodarstwach rodzinnych małej i średniej wielkości wyspecjalizowanych w hodowli bydła mlecznego i mięsnego. Niewielka część mieszkańców, 10\%, jest w stanie całkowicie utrzymać się z rolnictwa. Gmina podlega silnym procesom dezagraryzacji. Uprawy ziemi i hodowle skupione są w rękach właśnie tych nielicznych, wyspecjalizowanych gospodarstw rodzinnych. Wielu realnie bezrobotnych jest niezarejestrowanych, najczęściej są to kobiety, osoby młode lub w wieku 50+, gospodynie domowe, mieszkańcy byłych PGR-ów. Część z nich wyjeżdża sezonowo za granicę do pracy na farmach, przy opiece nad starszymi osobami i przy sprzątaniu. Popularne 
kierunki to Belgia, Niemcy i Norwegia. Dużym ograniczeniem w procesie szukania pracy jest też niskie wykształcenie. Aż 98\% mieszkańców ma wykształcenie średnie lub niższe, w tym 34\% podstawowe, $31 \%$ zawodowe, a 33\% średnie zawodowe i licealne. Jedynie 2\% kształciło się policealnie, co wskazuje na spore bariery edukacyjne.

Wszystkie te uwarunkowania - brak stałego i stabilnego zatrudnienia, niski poziom wykształcenia, wzorce migracji sezonowych jako doraźny sposób rozwiązywania problemów, brak zasobów finansowych w budżetach domowych i liczne ograniczenia infrastrukturalne (np. słabo rozwinięta sieć komunikacji z najbliższymi miastami) - pogłębiają nakładanie się procesów proletaryzacji i wykluczeń. Pokazują one również, że w gminie mimo idealnych warunków przyrodniczych dla (eko)turystyki i wypoczynku nie rozwinęła się adekwatnie agroturystyka.

Nakładające się wykluczenia pozostają w ścisłym związku z umacnianiem się - historycznie znaczących tutaj - wzorców patriarchalnych. W ostatnich wyborach parlamentarnych i prezydenckich miażdżącą popularność zdobyły populistyczne partie konserwatywne, dążące m.in. do ograniczenia praw kobiet i zacieśnienia związków z Kościołem katolickim. W wyborach do Sejmu PiS zdobył ok. 70\% głosów mieszkanek i mieszkańców gminy, podczas gdy PSL 20\% i Konfederacja 8\%. Podobne wyniki uzyskano w wyborach prezydenckich. To o wiele więcej niż średnia w Polsce. Podobne tendencje znajdziemy w samorządzie lokalnym. W radzie gminy znacząco przeważają mężczyźni, w sołectwach również, mimo znaczącego wzrostu udziału kobiet w tych ostatnich we współczesnej Polsce (zob. Matysiak 2014). Inne wskaźniki też nie pozostawiają wątpliwości. Mimo kryzysu w Polsce i na świecie, Kościół katolicki odgrywa w tej okolicy nadal kluczową, aktywną rolę w kontroli życia obyczajowo-rodzinnego. Jego znaczenie może ilustrować fakt, że nawet osoby, które identyfikują się jako ateiści lub niepraktykujący, z obawy przed społecznymi sankcjami, reprodukują praktyki parafialne, m.in. partycypują w dobrowolnym, rotacyjnym sprzątaniu kościoła lub kaplic przez mieszkańców i przekazują finansowe datki proboszczom. Obserwacje pokazują też, że w gminie dużym problemem jest przemoc w rodzinie. Jest ona jednak znormalizowana, uzwyczajniona, wpisana w codzienność. 
(Nie)mobilność, zamieszkiwanie oraz płeć w praktykach i dyskursach rozwodu

Co ciekawe, nie funkcjonuje ona oficjalnie w statystykach gminy, wskazywana jest jednak jako znaczący problem w gminnych, anonimowych badaniach (Program rewitalizacji dla gminy X na lata 2016-20234).

W takim kontekście nakładających się na siebie wykluczeń strukturalnych i patriarchalnych presji interesujące są wzorce praktyk wiejskich „pionierek rozwodu”. Stanowią one wraz z rozwiedzionymi mężczyznami margines, tylko $2 \%$ populacji. Większość, ok. $60 \%$, to małżeństwa, $28 \%$ panny/kawalerowie, $10 \%$ wdowy/cy. W poniższej analizie zaprezentuję studium przypadku Mirki, wielodzietnej mieszkanki wsi, której trajektoria rozwodu, (od)stawania się żoną, w interesujący i reprezentatywny jakościowo sposób odzwierciedla kluczowe wzorce (nie)mobilności, zamieszkania i pozostawania na terenach wiejskich. Wybór biografii Mirki podyktowany jest zatem jej zwyczajnością (typowością) w porównaniu do innych, zebranych przeze mnie w tej gminie 30 rodzinnych autobiografii narracyjnych kobiet. Jest to biografia ,pionierki”, pełna subwersywnych aktów nieposłuszeństwa, typowych w swoim przebiegu, choć jednocześnie wyjątkowych dla każdej spotkanej przeze mnie „pionierki” (zob. Okely 2015: 325).

Analiza przypadku Mirki i uchwycenie typowości - wyjątkowości wzorów praktyk i dyskursów, które tu znajduję nie byłoby możliwe bez trwającej od 2018 roku sześciomiesięcznej obserwacji uczestniczącej w gminie. W tym czasie brałam udział w codziennym życiu kilku gospodarstw domowych. Obserwowałam lokalną sferę publiczną i uczestniczyłam w różnego typu aktywnościach społeczności (Dniach Kobiet, festynach, imprezach rodzinnych, świętach religijnych). Prowadziłam swobodne wywiady etnograficzne z mieszkańcami i analizowałam dane zastane (archiwa szkół, albumy rodzinne, wydawnictwa i prasę lokalną). Wejście w kontekst i głębsze poznanie wzorców płci organizujących świat społeczny mieszkanek i mieszkańców gminy pozwoliło mi lepiej rozumieć doświadczenia kobiet zbierane w narracyjnych wywiadach autobiograficznych (prowadzonych metodą Fritza Schütze). Moje rozmówczynie pochodziły z ośmiu wsi, z trzech pokoleń kobiet w przedziale wieku 23-85

${ }^{4}$ Ze względu na anonimizację terenu badania nie podaję nazwy gminy zawartej w tytule raportu $\mathrm{z}$ badań. 
lat żyjących w tradycyjnych i nietradycyjnych konfiguracjach rodzinnych. Oprócz kobiet zamężnych z wielopokoleniowych domów były to kobiety rozwiedzione, w separacji, w drugich związkach, kohabitujące, żyjące w modelach razem - osobno lub określające się jako singielki/stare panny. Moje rozmówczynie pochodziły przede wszystkim z klasy ludowej, rzadziej średniej. Były rolniczkami lub pracownicami usług i sektorów opieki, matkami (1-5 dzieci), bezdzietnymi lub kobietami planującymi macierzyństwo. Wywiady trwały od 3 do 8 godzin, a większość z nich była prowadzona w lokalnym hoteliku robotniczym. W przypadku większości rozmówczyń już po wywiadach miałam okazję spotykać się ponownie, obserwować dalsze koleje losów rodzinno-zawodowych, a czasami też utrzymywać zażyłe relacje.

\section{Mirka. Studium przypadku (nie)mobilności, pozostawania i zamiesz- kania}

W momencie wywiadu Mirka ma ponad 40 lat i jest rozwiedzioną matką kilkorga dzieci. Od urodzenia mieszka we wsiach w badanej okolicy i podobnie jak inne ,pionierki rozwodu” nie chce wyprowadzić się do miasta ani za granicę. Podejmuje próby kilku krótkich wyjazdów, ale wraca na wieś. Ceni ją za bliskie relacje, swojskie i przyjacielskie sieci wsparcia, które można uruchomić w sytuacji kryzysu, bezrobocia lub bezdomności. Wiejska społeczność to dla Mirki mocny kapitał społeczno-kulturowy, który można przekuć na kapitał ekonomiczny i odwrotnie. Wieś ceni również za łatwiejszą możliwość reperowania budżetu dzięki własnemu ogrodowi czy pracom sezonowym. Mirka reprezentuje więc liczną kategorię osób, dla których wybór wsi jako miejsca zamieszkania nie jest „pozostawaniem w tyle” czy efektem braku zaradności, sprawczości i pomysłu na siebie (zob. Matysiak 2019).

Biografia Mirki to wzorcowy przykład doświadczeń wiejskich ,pionierek rozwodu", które aktywnie przejmują władzę i kontrolę nad swoim życiem przy wychodzeniu z patriarchalnych relacji małżeńskich. Źródła radzenia są zakotwiczone w wybranych tradycyjnych elementach tożsamości 
(Nie)mobilność, zamieszkiwanie oraz płeć w praktykach i dyskursach rozwodu

rolniczych kobiecości - zaradności, pracowitości, sile. Biografia Mirki reprezentuje dwa wzorce radzenia sobie, typowe dla praktyk ,pionierek” mieszkających na wsi.

Po pierwsze, są to praktyki przejścia ze schematu zorientowanego na poświęcenie i współzależność od męża i rodziny do schematu indywidualistycznego, zorientowanego na zabezpieczanie własności. Mirka wychodzi z porozwodowego kryzysu ubóstwa i groźby bezdomności, aktywnie rozwijając biograficzny plan zabezpieczania własności. Tym samym przejmuje większą kontrolę nad swoim życiem.

Po drugie, są to praktyki hipermobilności jako warunku pozostawania na wsi. Mirka jest wzorcowym przykładem mieszkanki wsi (rural stayers), która musi być hipermobilna, aby po rozwodzie móc zostać na wsi z wyboru. Praktyki te bazują na socjalizowanych wzorcach wiejskiej mobilności i poleganiu na kapitałach społecznych, kulturowych i ekonomicznych wiejskich wspólnot.

Mirka wychowuje się w rodzinie rolniczej od pokoleń, z utrwalonym tradycyjnym podziałem pracy. Oznacza to, że razem z matką opiekuje się domem i męskimi członkami rodziny. Sprząta, gotuje, pomaga w gospodarstwie. Niedługo po ukończeniu zawodówki wychodzi za mąż, po czym w krótkim odstępie czasu rodzi kilkoro dzieci. Razem z mężem zamieszkują w gospodarstwie teściów - w ich domu, w który Mirka inwestuje wszystkie swoje otrzymane od rodziców oszczędności.

Po kilku latach wspólnego życia, w trakcie którego rozmówczyni dzieli czas na pracę opiekuńczą w domu i gospodarstwie oraz drobne, dodatkowe prace opiekuńcze w sąsiednich wsiach, małżeństwo zaczyna się rozpadać. Na długo przed rozwodem, około 2010 roku mąż popada w ciągi alkoholowe, regularnie stosuje przemoc ekonomiczną i fizyczną. Teściowie nie reagują, w typowy sposób cedują winę za zachowanie syna na synową (zob. Urbańska 2016). Po wielu latach ukrywania przemocy przed społecznością wsi, rodziną i kręgiem znajomych, Mirka zmienia perspektywę. Podkreśla, że ,przestaje się wstydzić”. Zaczyna opowiadać i aktywnie szukać psychicznego wsparcia u bliskich - matki i przyjaciółek. Zaczyna też poważnie myśleć o rozwodzie, mimo iż, jak podkreśla, nie ma wiedzy o tym, jak to zrobić. W najbliższym otoczeniu 
dopiero pojawiają się wzorce rozwodu, z których mogłaby się uczyć. Jedyny punkt odniesienia to nieoficjalna separacja w bliskiej rodzinie Mirki oraz rozwód bezdzietnego małżeństwa z kręgu znajomych. Mimo to czuje się jak pionierka w tym obszarze praktyk, podobnie jak inne moje rozmówczynie. Cztery lata zajmuje jej podjęcie decyzji o rozwiązaniu małżeństwa.

W tym liminalnym czasie Mirka przestaje mieć opór przed korzystaniem ze wsparcia zewnętrznych instytucji. W pierwszej kolejności zakłada sprawę o alimenty, gdyż mąż regularnie przepija zarobek. W drugiej zaczyna wzywać policję w sytuacjach wszczynania przez niego burd (niszczenia mebli i fizycznej agresji): „Pierwszy raz mi przyszło wzywać policję na męża, bo [...] wszystko się rozgrywało w czterech ścianach. Nikt tego nie wiedział, nikt tego nie słyszał". Do tej pory mieszanie instytucji w ,prywatne sprawy rodziny” uważała za niewybaczalną zdradę. Nie wzywała policji również z innego powodu. Mąż ma w wiejskich kręgach lokalnych służb wielu kolegów i krewnych u władz. Mirka opowiada o nadużyciach męża (jeździe po pijanemu), na które znajomi policjanci przymykali oko. Takie patriarchalne koalicje wspierające sprawców na nieanonimowych obszarach wiejskich to typowy wzorzec, rozpoznawany nie tylko w Polsce. Po zmianie perspektywy ostrzega lokalnych policjantów, że w przypadku chronienia przez nich męża, sprawę skieruje wyżej. Kiedy zachowanie męża systematycznie się pogarsza, Mirka decyduje się na rozwód. Zakłada jednak, że po rozwodzie mąż wraz z teściami pozwolą jej mieszkać w jednej z części domu. Mirka nie wyobraża sobie innego scenariusza wyprowadzki, poza tym nie stać jej na samodzielny wynajem. Nie jest też prawnie współwłaścicielką domu, mimo że włożyła w remont wszystkie swoje oszczędności, a mężczyźni z jej rodziny pomagali przy rozbudowie. Jej genderowe wzorce interpretacji sytuacji i planowania przyszłości są do tej pory organizowane przez etykę troski i sprawiedliwości wspólnotowej. Jest przekonana, że mężowi i teściowej będzie zależeć na dobru kilkorga małych dzieci.

Plan wspólnego zamieszkania po rozwodzie jest wzorcem często spotykanym lub antycypowanym w biografiach moich, rozważających rozwód, rozmówczyń. Być może reprodukowane są tu wzorce (nie)oficjalnych 
(Nie)mobilność, zamieszkiwanie oraz płeć w praktykach i dyskursach rozwodu

separacji małżeństw zamieszkujących razem, czyli układy na wsi bardziej akceptowane i częściej widziane niż rozwód.

Wraz z rozwodem Mirka doświadcza trajektorii tułaczki i cierpienia, wraz z dziećmi balansuje na granicy ubóstwa i ryzyka bezdomności. Źródła tej sytuacji tkwią w nierównym dostępie mieszkanek wsi do własności, a tym samym władzy. Po pierwsze, Mirka jest przemocowo zmuszana do wyprowadzki. Mąż wraz z teściową w czasie mroźnej zimy odcinają prąd, ogrzewanie i wodę w zajmowanej przez nią i małe dzieci części domu:

No i się zaczęło. Zaczął się koszmar. [...] Odcięli mi prąd [...] na górze. [...] A to było wszystko u teściowej, gdzie, wiesz, jak ona zamknęła, to ja nie mogłam mieć nic, żadnego dostępu. Jest luty słuchaj. No wytłumacz dziecku, że on nie może bajki obejrzeć, [...] że ono nic nie może, no i wcześniej musi lekcje odrabiać, bo zima jest, luty, o czwartej jest już ciemno. Już po rozwodzie, to już kompletnie nie miałam tego prądu. No i co? Jak tu żyć? Silnie dawałam sobie radę bez tego prądu. Silnie, twardo siedziałam... e, no i w końcu znaleźli na mnie skuteczny sposób. Woda [...] Piątego marca zakręcili mi wodę i zamknęli piwnicę na kłódkę, więc nie miałam dostępu ani do pieca, ani do prądu, ani wody.

Mirka przez cały ten okres próbuje walczyć. Nie daje się wyrzucić z domu. Zimny pokój ogrzewa piecykiem gazowym, a dzieci odrabiają prace domowe przy świeczkach. Rezygnuje dopiero po zatruciu gazem i wyłączeniu przez teściową wody. Wyprowadza się razem z dziećmi do swojej rodziny kilka wsi dalej. W ciągu paru kolejnych lat rozmówczyni próbuje radzić sobie z nieustanną niepewnością i tymczasowością zamieszkania. Aktywnie szuka pomocy, korzystając ze wsparcia sieci społecznych. W tym kilkuletnim okresie, który nazywa ,tułaczką”, zmienia wraz z dziećmi cztery domy i, co się z tym wiąże, cztery wsie. Przez pierwsze półtora roku mieszka w ciasnym, starym domu u nadużywającej alkoholu rodziny. W surowych warunkach, bez ogrzewania i ciepłej wody: „No i tak, wyprowadziłam się tam, no i wcale słodko nie było, bo trzeba było stamtąd dzieciaki wozić. Było biednie. I było daleko. No 
i było [...] strasznie ciężko". Następnie, przez kolejny rok, wraz z dziećmi pomieszkuje w domu starszej osoby, którą odpłatnie się opiekuje. Po zmianie sytuacji rodzinnej pracodawców wyprowadza się. Wcześniej udaje się jej wynająć po znajomości starą, opuszczoną, zaniedbaną drewnianą chatę po zmarłej kilka lat wcześniej osobie. Dom ma kuchnię kaflową i wychodek na zewnątrz zamiast toalety. W zamian za niski czynsz i obietnicę przywrócenia domu do porządku może w nim mieszkać przez najbliższy rok:

Dom, w którym cztery lata nikt nie mieszka. Ktoś tam zmarł, tak więc tak. No szafa z tymi ubraniami, półki, wiadomo, no wszystko tak, jak ktoś umiera, jakby wychodził, nie ma go w domu, tak. I to trzeba było, no ten pan, który mi to wynajął, pozwolił mi to wszystko wynieść. Łóżka, na łóżkach były kołdry, pierzyny różne, wszystko mogę wywalić, wszystko. Do stodoły, to tam popakowałam i poustawiałam wory. [...] To taka rudera była, wiesz co, jakbyś ją zobaczyła dzisiaj, to byś, to byś powiedziała „o matko, gdzie ona poszła tam mieszkać".

Bo nie były godne warunki do życia. Takie wiesz, takie było to po prostu jakby yhm, chwilowe, przejściowe, jakbyś sobie mieszkała w jakimś baraku, chwilowym, bo dom masz, nie wiem, zalany dajmy na to. To nie były warunki dla dzieci.

Widać zatem, że ten okres kilku lat nieustannych zmian domów i wyprowadzek z kolejnych wsi to okres uzależnienia od wsparcia mieszkaniowego i ekonomicznego innych. Mirka doświadcza pomocy, ale równocześnie jest zależna od władzy innych: „niektórzy byli tacy wyniośli, tacy wiesz, każdy był panem swojego domu, a ja byłam takim nikim, takim malutkim człowieczkiem, który nie ma nic do powiedzenia”. To czas, kiedy mierzy się z biedą, wykluczeniem mieszkaniowym i transportowym (zawożenie dzieci do szkół, łączenie dojazdów z dorabianiem). W tym okresie funkcjonuje w surowych warunkach, czuje się jak „bezdomna”. Nikt, nawet najbliższa rodzina, nie chcą jej zameldować wraz z dziećmi.

Wzorzec systematycznej utraty kontroli nad stabilnością zamieszkania oraz doświadczanie skumulowanego chaosu i cierpienia, które 
(Nie)mobilność, zamieszkiwanie oraz płeć w praktykach i dyskursach rozwodu

obserwujemy w biografii Mirki mają mocne podstawy strukturalne. Oprócz instytucjonalnego braku zabezpieczenia przed przemocą i wykluczeniem mieszkaniowym wielodzietnych matek na wsi, kluczowe są tu wiejskie, genderowe wzorce nierówności w obszarze własności i dziedziczenia. Podobnie jak inne rozmówczynie, Mirka w czasie małżeństwa nie zabezpiecza swoich praw majątkowych. Do momentu rozwodu dominuje u niej orientacja troski. Jej istotą jest wzorzec poświęcenia swoich interesów na rzecz wielopokoleniowej wspólnoty. Prawo własności nie jest dla niej jako kobiety takim źródłem statusu i prestiżu, jakim jest dla męskich mieszkańców wsi. Dlatego w czasie małżeństwa nie zabezpiecza swoich praw do własności, a po rozwodzie nie myśli o wniesieniu do sądu sprawy o podział majątku czy zagwarantowanie rekompensaty finansowej. Nie zna też swoich praw lokatorskich - zakazu eksmisji zimą. Jak sama przyznaje w trakcie wywiadu, jeszcze będąc w małżeństwie, nie zastanawiała się, na jakiej zasadzie przysługuje jej prawo do wspólnego dorobku. Mimo iż zainwestowała w remonty i meble wszystkie oszczędności. Mąż zresztą nigdy nie włączył żony do współwłasności majątkowej domu i gospodarstwa, które pozostały zapisane na niego i teściów. A tuż przed samym rozwodem, aby uniknąć ewentualnego podziału majątku, w tajemnicy przed Mirką dogadał się ze swoją matką. Przepisał na nią w całości swoje prawa do części domu. Podobne wzorce mogłam zaobserwować u innych rozmówczyń - wiejskich ,pionierek rozwodu”. A lękowe antycypacje utraty zamieszkania i utraty „dorobku życia” u kobiet, które nie zdecydowały się z tego powodu odejść z nieudanego małżeństwa. Wiele z moich rozmówczyń obawia się utracić swój dorobek - meble i sprzęty kupione za oszczędności zbierane latami, nierzadko wysiłkiem całych rodzin.

Poradzenie sobie z niestabilnością zamieszkania przychodzi wraz z odziedziczeniem niewielkiego spadku, za który Mirka postanawia kupić swój własny dom. Jednak, aby mogło do tego dojść, Mirka musi złamać tradycyjne, nadal silne (jest 2015 rok) upłciowione wzorce obchodzenia się z „dziadkowizną”. Mirka bowiem chce sprzedać niewielką część starego domu po właśnie zmarłym krewnym (pokój z kuchnią) i kawałek rodzinnej ziemi z wielopokoleniowymi tradycjami jej uprawiania, które otrzymuje w spadku. W odziedziczonym i ciasnym domu jednak mieszka 
się jej źle, toczy się konflikt o metraż z rodziną, która dostała drugą połowę. Mirka postanawia więc ostatecznie rozwiązać swój problem z niestabilnością zamieszkania. Sprzedaje dom i kilka hektarów pola, czym narusza tradycyjny wzorzec przypisania ziemi do rodziny: „Krewny oczywiście powiedział do mnie, jak ty sprzedasz dziadkowiznę, to w ogóle się nie pokazuj u mnie, się nie odzywaj do mnie". Wzorce te są istotne lokalnie, tym bardziej, że wieś ma u miejscowych status wsi szlacheckiej. Mirka jednak łamie tradycję, której częścią jest męska symboliczna kontrola nad dziedziczeniem i decyzjami o przeznaczeniu ziemi. Za sprzedaną ziemię i dom kupuje kilka wsi dalej stary dom w ruinie z niewielkim kawałkiem ogrodu. Mimo oporów rodziny, Mirka i wspierająca ją znajoma z dużego miasta widzą w nim potencjał: ,tylko ona w sumie wierzyła w te, w te powodzenie tego, że to się da ogarnąć to wszystko, tak. Bo to no ruina w sumie była, bo to nie można było tego inaczej nazwać”; „takie były chaszcze, że nie było tego domu widać”; „tam wody nie było i szamba nie było”; „zrobimy sobie kibelek, będziemy się myć w misce, tak jak do tej pory myliśmy się w misce w wynajmowanym domu". Decyzję pomaga podjąć fakt, że dom jest bardzo tani, stoi obok dobrej drogi dojazdowej, z której dzieci mają blisko do szkoły. W bardzo krótkim czasie mobilizuje wszystkie swoje kapitały i sieci społeczne, aby dom minimalnie przystosować do szybkiego zamieszkania.

Biografia Mirki reprezentuje więc dwa typowe dla praktyk ,pionierek rozwodu" mieszkających na wsi wzorce radzenia sobie z zamieszkaniem.

Najważniejszym jest wzorzec przejścia ze schematu zorientowanego na poświęcenie i współzależność kobiety od męża i wielopokoleniowej rodziny do schematu indywidualistycznego, zorientowanego na zabezpieczanie własności. Kupno starego domu symbolicznie wieńczy i zamyka subwersywną przemianę tożsamościową Mirki. Jej początek wyznacza plan rozwodu i aktywny proces ucieczki z zależności patriarchalnych, a kończy plan zabezpieczenia własności, a tym samym odzyskania władzy nad swoim życiem. Mirka, próbując nazwać ten okres, sama o sobie mówi, że zmieniła się z „szarej malutkiej myszki, co to nic nie wiedziała o życiu, nic nie wiedziała kompletnie” w „silną”, „mocną”, „wolną”, „nieustraszoną”, „panią swojego życia”. W procesie przemiany odkrywa 
(Nie)mobilność, zamieszkiwanie oraz płeć w praktykach i dyskursach rozwodu

więc nowe wartości - poczucie siły, wolności i władzy nad swoim życiem, których fundamentem staje się indywidualna własność: „To było takie silne we mnie, mieć coś swojego. Przecież wyszłam z rodziny, z domu od męża nie biorąc nic”; „Ja miałam wtedy taką moc, słuchaj, takiego powera, że mnie nic nie przerażało. Nic. Kompletnie. Bo to miało być moje"; „To było po prostu wręcz nie do uwierzenia, że tak się może życie zmienić. $\mathrm{Z}$ takiej, z takiej szarej malutkiej myszki, co to nic nie wiedziała o życiu. Nic nie wiedziała kompletnie i raptem takie wielkie »HELLO«. Bo ja naprawdę dokonałam [...], że tak powiem niemożliwego". Mirka podkreśla z dumą swój nowy status wielokrotnie: ,jestem panią swojego domu i panią swojego życia. I mną już nikt nie może zawładnąć i zarządzić, bo mi wszyscy moga naskoczyć, że tak powiem. TAK!’. Sednem tej przemiany jest przekierowanie tradycyjnych elementów wiejskich tożsamości kobiet, takich jak zaradność, pracowitość i siła, w indywidualne projekty życiowe, zamiast w nierówne relacje patriarchalne z mężem i starszymi członkami rodziny. Indywidualizm polega tu zatem na takiej organizacji życia, która jest przede wszystkim pomyślana poza zależnością od męża lub męskiego partnera, częścią nowego projektu jest również zapewnienie stabilnej codzienności dzieciom. Mirka podkreśla również, że jej nowa tożsamość i pionierskie praktyki są zauważane w wiejskiej społeczności: „A ludzie sama wiesz, jak reagowali. To było zainteresowanie wielkie, jak ja kupiłam te chaszcze, wiesz. Zaczęliśmy wyrywać, i to było wielkie zainteresowanie".

Drugim równie istotnym wzorcem radzenia sobie ,pionierek rozwodu” są praktyki hipermobilności jako warunku pozostania na wsi. Mirka jest wzorcowym przykładem mieszkanki wsi, która musi być hipermobilna, aby po rozwodzie móc tu zostać z wyboru. Praktyki te bazują na socjalizowanych wzorcach wiejskiej mobilności i korzystaniu z wypracowanych kapitałów społecznych, kulturowych i ekonomicznych wiejskich wspólnot. Mirka jest tu wzorcowym przykładem mieszkanki wsi od dzieciństwa socjalizowanej do mobilności i migracji. Wzorce te są budowane przez przekazy międzygeneracyjne (rodzice migrowali między wsiami), konieczność dojeżdżania do szkół czy miejsc pracy rozrzuconych po różnych wsiach i miasteczkach (praca w opiece, akwizycji, na produkcji). 
Presja nieustannej mobilności, koniecznej, by na wsi móc się utrzymać i pozostać sprawia, że Mirka bardzo wcześnie musi maksymalizować zdolność do przemieszczania się. Gdy tylko osiąga pełnoletność, wyrabia prawo jazdy. Musi też być elastyczna rezydencjalnie. Bardzo wcześnie, już w szkole zawodowej, przenosi się między wsiami; próbuje wraz ze znajomymi wynajmować mieszkania w pobliżu miejsc pracy. W ramach tych doświadczeń rozwija umiejętności społeczne, łatwość nawiązywania kontaktów, budowania kapitałów społecznych, tworzenia sieci wsparcia i pomocy: „no już byłam takim człowiekiem, gdzie wszędzie mnie było pełno”; „umiałam się odnaleźć w każdym towarzystwie”. Umiejętności te wraz z tradycyjnymi, patriarchalno-katolickimi wzorcami kobiecości tworzą skomplikowaną, niejednoznaczą, ambiwalentną tożsamość Mirki (w tym innych wiejskich kobiet).

Wzorce radzenia sobie z kryzysami opisane w biografii Mirki pojawiają się $\mathrm{w}$ różnych wariantach $\mathrm{w}$ innych wywiadach $\mathrm{z}$,pionierkami rozwodu”. Pojawiają się też w czasie obserwacji uczestniczących, które prowadzę w gminie. U innych kobiet dochodzą do tego również praktyki poszukiwania wsparcia instytucji, np. mieszkań socjalnych w gminie czy wymaganie pomocy od księży w postaci oczekiwania czasowego przyjęcia „pod dach” plebanii. Niektóre z rozmówczyń po reorientacji na indywidualną własność, w kolejnych związkach już po rozwodzie (tzw. drugie związki) wybierają model zamieszkania razem - osobno nawet w sytuacji posiadania wspólnych dzieci. Obecność takich konstruowanych przez „pionierki” wzorców radzenia sobie z kryzysami można zaobserwować w codziennych interakcjach mieszkańców. Biografie ,pionierek rozwodu” stają się tu punktem odniesienia. Mają one realny wpływ na poszerzanie repertuarów realnych możliwości o czym wielokrotnie przekonałam się w czasie obserwacji uczestniczących z kobietami, które rozważają odejście z małżeństwa i antycypują różne scenariusze. Jeśli wynajem lub kupno domu są poza możliwościami budżetowymi rozmówczyń, zazwyczaj antycypowane są scenariusze powrotu do domu rodziców lub osoby sprzyjającej w rodzinie. Nie bez znaczenia są tu również możliwości łączenia pracy opiekuńczej nad starszą osobą z zamieszkaniem. Opcja coraz bardziej dostępna dla kobiet w związku z procesami starzenia się 
(Nie)mobilność, zamieszkiwanie oraz płeć w praktykach i dyskursach rozwodu

wsi i depopulacją. Nierozpoznany jest też w literaturze - zajmującej się przede wszystkim wiejską gentryfikacją i miejskimi właścicielami drugich domów na wsi - popularny wzorzec zakupu i remontów starych, pozbawionych podstawowych wygód i instalacji, tanich domów. Fenomen ten wymagałby oddzielnych badań, z włączeniem obejmującej również rozwodzących się mężczyzn perspektywy genderowej. Ścieżki zamieszkiwania tych ostatnich bowiem różnią się od analogicznych ścieżek kobiet, głównie z uwagi na pozostawanie dzieci po rozwodzie u matki i większe zapotrzebowanie na pracę mężczyzn w rolnictwie. Mężczyźni łatwiej znajdują kąt do spania w gospodarstwach rolnych i na farmach w zamian za pracę fizyczną tam wykonywaną. Często też zdarza się, że, uzależnieni od alkoholu, przeprowadzają się po rozwodzie do pomieszczeń gospodarczych lub stodoły. Z kolei matki z dziećmi mogą znaleźć dach nad głową, jeśli podejmą stacjonarną opiekę nad osobami zależnymi.

\section{Podsumowanie}

Pokazanie wzorców (nie)mobilności i zamieszkiwania wiejskich ,pionierek rozwodu" jest cennym uzupełnieniem wiedzy o złożoności przemian społecznych na wsi.

Po pierwsze, analiza ta pokazuje relację między nierównościami płci w rodzinie i społeczności a walką o to, aby po rozpadzie małżeństwa móc na wsi pozostać i tam przynależeć. Uzupełnia tym samym wiedzę o innych niż migracje za granicę lub ucieczki do miast wzorcach radzenia sobie z nową sytuacją społeczno-mieszkaniową po rozwodzie. Dzięki analizie doświadczeń ,,pionierek rozwodu” możemy przyjrzeć się nie tylko kwestiom upłciowienia wiejskiego mieszkalnictwa, czy ryzykom bezdomności i ubóstwa wiejskich kobiet, zwłaszcza wielodzietnych matek. Możemy również przyjrzeć się przemianom wzorców płci w obszarze własności i dziedziczenia na wsi. Indywidualizacja własności, w tym przypadku praktyki nabywania domów przez samotne/samodzielne matki, jest postrzegana jako mocny wyłom, zmiana pozycji i hierarchii władzy między płciami w społecznościach wiejskich. Widzimy zatem, jak wraz 
z procesami detradycjonalizacji wzorców małżeństwa, rodziny oraz własności rodzi się sprawstwo i innowacyjność kobiet.

Po drugie, przyjmując perspektywę (nie)mobilności podkreślającą sprawstwo osób pozostających we wsiach z wyboru, mamy okazję wyjaśnić, co umożliwia mieszkankom konserwatywnych wsi negocjowanie bardziej nowoczesnych wzorców życia. Dla kobiet z klas ludowych jest to paradoksalnie możliwe dzięki zakorzenieniu w lokalnych, konserwatywnych rodzinno-sąsiedzkich sieciach, będących głównymi źródłami wsparcia i kapitałów.

Po trzecie, te nowe wzorce życia po rozwodzie i strategie oporu wobec upłciowionych porządków moralnych powinny być też postrzegane w kategoriach wiejskich innowacji. W tym przypadku praktyk, które są ważne dla równości, a dzięki temu dla lepszej jakości życia w wiejskich społecznościach. Z takiej perspektywy można też krytycznie dyskutować z orientalizującymi i metronormatywnymi wizjami wsi, które nowoczesność kojarzą wyłącznie z miastem.

Po czwarte, studium Mirki uzupełnia wiedzę o nowych właścicielach domów na wsi. Strukturę ich posiadaczy tworzą więc nie tylko poszukujący nowego stylu życia miejscy nabywcy, ale też, podobne do Mirki, wiejskie innowatorki. Choć analizy pokazują, że dezagraryzacji polskich wsi towarzyszy ich rosnąca proletaryzacja, a więc zwiększanie się udziału klasy robotniczej w strukturze wsi (Halamska 2016), badania nad wiejską gentryfikacją czy mieszkalnictwem skupiają się prawie wyłącznie na migrantach z miejskiej klasy średniej (Laskowska-Otwinowska 2008; Heffner, Czarnecki 2011; Kajdanek 2015; Śpiewak 2016). Nierozpoznana jest rola klasy ludowej w relacji do gentryfikacji na peryferiach czy suburbiach. Nierozpoznana jest też relacja między mobilnością klasy ludowej między wsiami a praktykami nabywania tam drugich domów przez mieszkańców miast. Opisywany tu m.in. wzorzec przemieszczania się między wsiami i wynajmowanie albo kupowanie tanich, starych domów, będące warunkiem pozostania tam, ma szansę uzupełnić wiedzę o wzorcach wewnętrznej mobilności, a przede wszystkim jej upłciowionych i klasowych wymiarach. 
(Nie)mobilność, zamieszkiwanie oraz płeć w praktykach i dyskursach rozwodu

\section{Bibliografia}

Bernini, S. (2020). Marrying and divorcing in postwar Europe. Ideological Struggles Across the Iron Curtain. Venezia: Edizioni Ca'Foscari.

Bukraba-Rylska, I. (2008). Rodzina wiejska. W: I. Bukraba-Rylska (red.), Socjologia wsi polskiej (s. 135-157), cz. II. Warszawa: Wydawnictwo Naukowe PWN.

Clark, W.A.V.(2013). Life course events and residential change: Unpacking age effects on the probability of moving. Journal of Population Research, 30 (4), 319-334. doi: 10.1007/s12546-013-9116-y

Dunn, E. (2007). Prywatyzując Polskę. O bobofrutach, wielkim biznesie i restrukturyzacji pracy (przeł. P. Sadura). Warszawa: Wydawnictwo Krytyki Politycznej.

Gorlach, K., Drąg, Z. (2011). Kobiety na kombajnach: właścicielki gospodarstw rolnych w Polsce współczesnej. W: K. Slany, J. Struzik, K. Wojnicka (red.), Gender w społeczeństwie polskim (s. 280-29). Kraków: Nomos.

Gospodarczyk, M. (2019). Rolnicy, kowboje i drwale. Koncepcje wiejskich męskości w obszarze badań nad wsią. Studia Socjologiczne, 4, 103-128. doi: 10.24425/sts.2019.126158

Halamska, M. (2011). Wprowadzenie. Wieś w wielodyscyplinarnym oglądzie. W: M. Halamska (red.), Wieś jako przedmiot badań naukowych na początku XXI wieku (s. 11-28). Warszawa: WN Scholar.

Haugen, M., Brandth, B. (2015). When Farm Couples Break Up: Gendered Moralities, Gossip and the Fear of Stigmatisation in Rural Communities. Sociologia Ruralis, 55, 227-242. doi: 10.1111/SORU.12065

Haugen, M., Brandth, B., Follo, G. (2015). Farm, family, and myself: farm women dealing with family break-up. Gender, Place \& Culture, 22, 37-49. doi: 10.1080/0966369X.2013.855708

Haugen, M., Villa, M. (2006). Big Brother in rural societies: Youths' discourses on gossip. Norsk Geografisk Tidsskrift - Norwegian Journal of Geography, 60, 209-216. doi: 10.1080/00291950600889996 
Haukanes, H. (2013). Belonging, mobility and the future: Representations of space in the life narratives of young rural Czechs. Young: Nordic Journal of Youth Research, 21 (2), 193-210. doi: 10.1177/1103308813477467. Hjalm, A. (2014). The 'Stayers': Dynamics of lifelong sedentary behaviour in an urban context. Population, Space and Place, 20 (6), 569580. doi: 10.1002/psp.1796

Hughes, A. (1997). Rurality and 'Cultures of Womanhood': Domestic identities and moral order in village life. In: P. Clocke, J. Little (eds.), Contested Countryside Cultures. Otherness, marginalisation and rurality (p. 118-133). London: Routledge.

Klich-Kluczewska, B. (2015). Rodzina, tabu i komunizm w Polsce 19561980. Kraków: Wydawnictwo LIBRON.

Knapik, W. (2008). Kobieta w wiejskiej społeczności lokalnej. Toruń: Wydawnictwo Adam Marszałek.

Kowalska-Lewicka, A. (1971). Tradycyjne normy obyczajowe w kontaktach młodzieży na Podhalu. Roczniki Socjologii Wsi, t. 11, 23-35.

Krzyworzeka, A. (2014). Rolnicze strategie pracy i przetrwania. Studium z antropologii ekonomicznej. Warszawa: WUW.

Little, J. (2007). Gender and sexuality in rural communities. In: P. Cloke, T. Mardsen, P.H. Mooney (eds.), Handbook of rural studies (p. 365378). London: Sage.

Little, J. (1987). Gender relations in rural areas: the importance of women's domestic role. Journal of Rural Studies, 3 (4), 335-42.

Looker, D., Naylor, T. (2009). 'At risk' of being rural? The experience of rural youth in a risk society. Journal of Rural and Community Development, 4 (2), 39-64.

Matysiak, I. (2014). Rola sołtysów we współczesnych społecznościach wiejskich. Płeć jako czynnik różnicujący kapitał społeczny. Warszawa: Wydawnictwo Scholar.

Matysiak, I. (2019). Młodzi i wykształceni w procesie przemian polskiej wsi. Warszawa: Wydawnictwo Scholar.

Michalska, S. (2015). Tradycyjni aktorzy w nowych rolach - zmiany ról kobiet wiejskich jako przykład zmian społecznych na wsi. W: H. Podedworna, A. Pilichowski, W. Knieć (red.), Nowi sprawcy 
(Nie)mobilność, zamieszkiwanie oraz płeć w praktykach i dyskursach rozwodu

zmian społecznych na wsi (s. 124-139). Warszawa: Wydawnictwo SGGW.

Michalska, S. (2016). Domestic Violence Against Women in Rural Communities in Poland [Przemoc domowa wobec kobiet w społecznościach wiejskich]. Wieś i Rolnictwo, 4(173), 141-162. doi: 10.53098/ wir042016/08

Michalska, S. (2019). Rodzina wiejska w genderowej perspektywie, czyli o sytuacji kobiet. W: M. Halamska, M. Stanny, J. Wilkin (red.), Ciągłość i zmiana. Sto lat rozwoju polskiej wsi (s. 287-321), t. 1. Warszawa: IRWiR PAN, WN Scholar.

Mohl, P. (1997). Village voices. Coexistence and communication in a rural community in central France. Copenhagen: Museum Tusculanum Press, University of Copenhagen.

Mostowska, M., Dębska, K. (2020). 'Where was I to go after divorce?': Gendered Family Housing Pathways and Women's Homelessness in Poland. European Journal of Homelessness, 14 (2), 45-69.

Ni Laoire, C. (2001). A matter of life and death? Men, masculinities and staying 'behind' in rural Ireland. Sociologia Ruralis, 41 (2), 220-236. doi: 10.1111/1467-9523.00179

Niczyporuk, D. (2004). Przemoc w kulturze wsi. Niebieska Linia, 5. Pozyskano z https://www.niebieskalinia.pl/pismo/wydania/dostepne-artykuly/4426-przemoc-w-kulturze-wsi.

Nugin, R. (2014). I think they should go. Let them see something. Journal of Rural Studies, 34, 51-64. doi: 10.1016/j.jrurstud.2014.01.003

Okely, J. (2015). Chwile buntu, płeć, opór i jednostka. W: A. Pasieka, K. Zielińska (red.), Opór i dominacja. Antologia tekstów (s. 318-341). Kraków: Zakład Wydawniczy NOMOS.

Philo, C., Parr, H., Burns, N. (2017). The rural panopticon. Journal of Rural Studies, 51, 230-239. doi: 10.1016/j.jrurstud.2016.08.007

Pine, F. (2007). Góralskie wesele. Pokrewieństwo, płeć kulturowa i praca na terenach wiejskich socjalistycznej i postsocjalistycznej Polski. W: A. Kościańska, R.E. Hryciuk (red.), Gender. Perspektywa antropologiczna, t. 1: Organizacja społeczna (s. 76-91). Warszawa: WUW. 
Shortall, S. (2017). Gender and Agriculture. In: B. Bock, S. Shortall (eds.), Gender and Rural Globalization. International Perspectives on Gender and Rural Development (p. 89-99). Wallingford, Oxfordshire: CABI.

Stanisz, A. (2013). Rodzina made in Poland. Antropologia pokrewieństwa i życia rodzinnego. Poznań: Wydawnictwo Nauka i Innowacje.

Stockdale, A., Haartsen, T. (2018). Editorial introduction: Putting rural stayers in the spotlight. Population Space Place, 2018, 24:e2124. doi: $10.1002 / p s p .2124$

Szpak, E. (2013). Mentalność ludności wiejskiej w PRL. Studium zmian. Warszawa: Scholar.

Thomassen, J.A.K. (2021). The roles of family and friends in the immobility decisions of university graduates staying in a peripheral urban area in the Netherlands. Popul Space Place, 2021, 27:e2392. doi: 10.1002/ psp. 2392

Tryfan, B. (1987). Kwestia kobieca na wsi. Warszawa: PWN.

Tryfan, B., Grabowicz, J. (1962). Wzrost rozwodów a kryzys małżeństwa. Wieś Współczesna, 8, 82-93.

Urbańska, S. (2016). Transnational Motherhood and Forced Migration. Causes and Consequences of the Migration of Polish Working-Class Women 1989-2010. Central Eastern European Migration Review, 5 (1), 109-128. doi: 10.17467/ceemr.2016.11

Urbańska, S. (2011). W metrze straszy. O kampanii „Rozwód? Przemyśl to!”. Kultura Liberalna, 143 (40/2011). Pozyskano z https://kulturaliberalna.pl/2011/09/27/poniedzialek-warszawa-jest-kobietaurbanskaw-metrze-straszy-o-kampanii-\%e 2\%80\%9erozwod-przemyslto $\% \mathrm{e} 2 \% 80 \% 9 \mathrm{~d} /$.

Urbańska, S. (2015). Matka Polka na odległość. Z doświadczeń migracyjnych robotnic 1989-2010. Toruń: Wydawnictwo Uniwersytetu Mikołaja Kopernika.

Urbańska, S. (2018). Gender, Families, Social Change, And The RuralUrban Discourse: The Polish Peasant In Europe And America As a Study of Fears and Fantasies Related to Modernisation. Stan Rzeczy, 2 (15), 111-139. doi: 10.14394/srz.15.8 
(Nie)mobilność, zamieszkiwanie oraz płeć w praktykach i dyskursach rozwodu

Zdanowicz, A. (2017). Problematyka emancypacji na łamach „Wiadomości Kobiecych" 1931-1933. Rocznik Historii Prasy Polskiej, 20 (1), 43-62. 